\title{
DETERMINAN NILAI PERUSAHAAN DENGAN KINERJA KEUANGAN SEBAGAI VARIABEL INTERVENING
}

\author{
Tri Neliana ${ }^{\bowtie}$, Rina Destiana \\ Universitas Swadaya Gunung Jati, Cirebon, Indonesia \\ nelianatri@gmail.com, destirin@gmail.com \\ https://doi.org/10.46367/jas.v5i2.430
}

Received: Oct 31, 2021 Revised: Dec 14, 2021 Accepted: Dec 16, 2021 Published: Dec 21, 2021

\begin{abstract}
This study aims to show the effect of institutional ownership, audit committee size, and corporate social responsibility (CSR) on firm value with financial performance as the intervening variable. This study uses quantitative methods with secondary data sources in company annual reports. The population of this study is manufacturing companies listed on the Indonesia Stock Exchange (IDX) for the 2018-2020 period. The sampling technique used purposive sampling to obtain a sample of 74 companies. The data analysis technique used path analysis. The results showed that financial performance had a positive and significant effect on firm value. Institutional ownership and size of the audit committee do not affect financial performance. Meanwhile, CSR has a positive and significant effect on financial performance. Institutional ownership and the size of the audit committee have a positive and significant effect on firm value. At the same time, CSR does not affect the company's value. Institutional ownership does not affect firm value through financial performance. At the same time, the size of the audit committee and CSR affects the company's value through financial performance. This study can reference company management and investors in developing companies and investing.
\end{abstract}

Keywords: Institutional Ownership, Audit Committee Size, Corporate Social Responsibility, Company Value, Financial Performance.

\begin{abstract}
ABSTRAK
Penelitian ini bertujuan untuk memperlihatkan pengaruh kepemilikan institusional, ukuran komite audit dan corporate social responsibility (CSR) terhadap nilai perusahaan dengan kinerja keuangan sebagai variabel intervening. Penelitian ini menggunakan metode kuantitatif dengan sumber data sekunder berupa laporan tahunan perusahaan. Populasi penelitian ini adalah perusahaan manufaktur yang terdaftar di Bursa Efek Indonesia (BEI) periode 2018-2020. Teknik pengambilan sampel menggunakan purposive sampling, sehingga diperoleh sampel sebanyak 74 perusahaan. Teknik analisis data menggunakan analisis jalur. Hasil penelitian menunjukkan bahwa kinerja keuangan berpengaruh positif dan signifikan terhadap nilai perusahaan. Kepemilikan institusional dan ukuran komite audit tidak berpengaruh terhadap kinerja keuangan. Sedangkan $C S R$ berpengaruh positif dan signifikan terhadap kinerja keuangan. Kepemilikan institusional dan ukuran komite audit berpengaruh positif dan signifikan terhadap nilai perusahaan. Sedangkan CSR tidak berpengaruh terhadap nilai perusahaan.
\end{abstract}


Kepemilikan institusional tidak berpengaruh terhadap nilai perusahaan melalui kinerja keuangan. Sedangkan ukuran komite audit dan CSR berpengaruh terhadap nilai perusahaan melalui kinerja keuangan. Penelitian ini dapat menjadi acuan bagi manajemen perusahaan dan investor dalam mengembangkan perusahaan dan menanam modal.

Kata Kunci: Kepemilikan Institusional, Ukuran Komite Audit, Corporate Social Responsibility, Nilai Perusahaan, Kinerja Keuangan.

\section{PENDAHULUAN}

Perkembangan perusahaan dalam berbagai sektor di era globalisasi semakin maju, hal ini memicu munculnya persaingan yang ketat. Semakin banyaknya perusahaan manufaktur yang terdaftar di BEI dari tahun ke tahun menunjukkan persaingan yang semakin ketat dalam rangka menarik investor untuk menanamkan modalnya pada perusahaan. Perusahaan manufaktur pada kenyataannya tidak selalu mengalami peningkatan pada nilai perusahaan, hal ini ditunjukkan dengan nilai indeks manufaktur yang turun dari 50\% menjadi 48,5\% pada bulan Mei 2017. Penurunan indeks tersebut menunjukkan bahwa sektor manufaktur mengalami kelesuan (Kemenperin 2017). Namun pada masa pandemi covid-19 perusahaan manufaktur malah tumbuh secara agresif (Kemenperin 2021). Hal tersebut menunjukkan fenomena bahwa sektor manufaktur mengalami fluktuatif. Peran manajemen sangat penting karena mereka memiliki informasi tentang kondisi perusahaan yang sesungguhnya sehingga diharapkan mampu mengelola perusahaan dengan baik sesuai keinginan pemilik perusahaan.

Keberadaan kepemilikan institusional yang besar diharapkan dapat memonitor kinerja manajemen untuk memotivasi manajer dalam meningkatkan nilai perusahaan. Kepemilikan institusional merupakan saham dalam perusahaan yang dimiliki oleh investor institusional seperti pemerintah, lembaga keuangan, perusahaan asuransi dan institusional lainnya (Nugroho and Yulianto 2015). Pengawasan fungsi pengelolaan perusahaan juga dilakukan oleh komite audit yang berperan sebagai pihak independen dalam memberikan pendapat kepada dewan komisaris terkait dengan sistem pengawasan internal perusahaan. Komite audit merupakan salah satu badan atau komite yang membantu tugas komisaris dalam bidang kebijakan akuntansi, pengawasan internal maupun pelaksanaan laporan keuangan (Sutedi 2012, 161). Oleh karena itu, keberadaan komite audit diharapkan dapat melakukan pengawasan kepada manajer untuk meningkatkan nilai perusahaan. Perusahaan dituntut tidak hanya mengutamakan kepentingan pemilik modal semata, karena hal ini dapat menimbulkan kesenjangan sosial dan kerusakan lingkungan sekitar. Oleh karena itu, kesadaran dan kepedulian perusahaan terhadap lingkungan sekitarnya diperlukan melalui pengungkapan tanggung jawab sosial perusahaan $(C S R)$. Melalui $C S R$ perusahaan tidak hanya berorientasi kepada pemilik modal (investor dan kreditor) tetapi juga terhadap pihak lain yang juga berkepentingan seperti konsumen, karyawan, masyarakat, dan pemerintah.

Penelitian tentang pengaruh kepemilikan institusional terhadap nilai perusahaan sudah pernah dilakukan oleh Murwaningsari (2009); Sukirni (2012); Adnantara (2013); Purbopangestu and Subowo (2014); Susanti and Mildawati (2014); Mukhtaruddin, Relasari, and Felmania (2014); Bilayudha and Kiswanto 
(2015); Widyasari, Suhadak, and Husaini (2015) dengan menunjukkan keberagaman hasil. Kemudian penelitian mengenai pengaruh ukuran komite audit terhadap nilai perusahaan juga sudah pernah dilakukan oleh Mukhtaruddin, Relasari, and Felmania (2014); Purbopangestu and Subowo (2014); Bilayudha and Kiswanto (2015); Widyasari, Suhadak, and Husaini (2015); Sukmono and Yadiati (2016); Onasis (2016) dengan hasil yang beragam juga. Selanjutnya penelitian mengenai pengaruh $C S R$ terhadap nilai perusahaan juga sudah pernah dilakukan oleh Wardhani (2013); Muthmainah (2015); Patmawati (2016); Fawaid (2016); Rachmania (2017); Ardiyanto and Haryanto (2017) dengan hasil yang beragam pula.

Penelitian mengenai kinerja keuangan dalam memediasi pengaruh $C S R$ terhadap nilai perusahaan sudah pernah dilakukan oleh Wardhani (2013); Fawaid (2016); Patmawati (2016); Ardiyanto and Haryanto (2017); Alkhairani, Kamaliah, and Rokhmawati (2020) dengan hasil yang beragam. Penelitian mengenai kinerja keuangan dalam memediasi pengaruh kepemilikan institusional terhadap nilai perusahaan sudah pernah dilakukan oleh Mastuti and Prastiwi (2021). Namun penelitian mengenai kinerja keuangan dalam memediasi pengaruh ukuran komite audit terhadap nilai perusahaan belum ditemukan, sehingga hal tersebut dapat membedakan dengan penelitian yang sudah ada. Kemudian berdasarkan penelitian yang sudah ada maka perlu dilakukan penelitian ulang dengan objek dan data yang berbeda, sehingga dapat menambah kekurangan dari penelitian yang sudah ada. Penelitian ini bertujuan untuk menunjukkan apakah kinerja keuangan berpengaruh terhadap nilai perusahaan. Kemudian untuk menunjukkan apakah kepemilikan institusional, ukuran komite audit dan CSR secara parsial berpengaruh terhadap kinerja keuangan. Selanjutnya menunjukkan apakah kepemilikan institusional, ukuran komite audit dan CSR secara parsial berpengaruh secara langsung atau tidak langsung terhadap nilai perusahaan yang dimediasi oleh kinerja keuangan.

\section{TELAAH LITERATUR}

Teori stakeholder (stakeholder theory) merupakan sebuah konsep yang pertama kali dipopulerkan oleh Freeman (1984). Stakeholder merupakan kelompok atau individu yang dapat mempengaruhi atau dipengaruhi oleh pencapaian tujuan organisasi (Freeman 1984). Ghozali and Chariri $(2014,439)$ mengatakan bahwa dalam stakeholder theory, perusahaan harus memberikan manfaat bagi stakeholdersnya antara lain pemegang saham, kreditor, konsumen, supplier, pemerintah, masyarakat, analis dan pihak lain. Keberadaan dan dukungan stakeholder sangatlah mempengaruhi suatu perusahaan.

Teori keagenan (agency theory) merupakan konsep yang dipopulerkan oleh Jensen and Meckeling (1976). Keagenan merupakan kerjasama antara principal dan penyalur, dimana principal memberikan kekuasaan kepada penyalur untuk melakukan bisnis dan membuat ketetapan yang berkaitan. Teori keagenan merupakan kerjasama yang menyertakan pihak pemilik dana dan pengelola dana (Jensen and Meckeling 1976).

Teori sinyal (signaling theory) merupakan konsep yang dikemukakan pertama kali oleh Spence (1973). Teori sinyal merupakan cara pandang para pemegang saham perusahaan tentang peluang perusahaan dalam meningkatkan 
nilai perusahaan di masa yang akan datang, berdasarkan informasi yang diberikan oleh manajemen perusahaan. Informasi tersebut disampaikan guna memberikan isyarat kepada para pemegang saham atau investor mengenai manajemen perusahaan dalam melihat prospek perusahaan di masa yang akan datang sehingga dapat membedakan perusahaan berkualitas baik dan perusahaan yang dinilai buruk (Spence 1973).

\section{Kinerja Keuangan Dan Nilai Perusahaan}

Kinerja keuangan perusahaan dapat dilakukan dengan menggunakan analisis rasio keuangan (Sanjaya and Rizky 2018). Rasio profitabilitas dalam bentuk return on asset (ROA) dapat mengukur seberapa efektif perusahaan bagi para investor. Semakin baik nilai $R O A$ maka secara teoritis kinerja keuangan perusahaan dikatakan baik, yang berakibat pula naiknya harga saham perusahaan dan akan menarik minat investor untuk menanamkan modalnya pada perusahaan (Padmayanti, Suryandari, and Munidewi 2019). Antara profitabilitas dengan harga saham akan terjadi hubungan yang positif yang pada akhirnya harga saham yang tinggi akan mempengaruhi nilai perusahaan (Suffah and Riduwan 2016).

Profitabilitas perusahaan yang tinggi maka akan meningkatkan laba per saham perusahaan. Adanya peningkatan laba per lembar saham perusahaan akan membuat investor tertarik untuk menanamkan modalnya dengan membeli saham perusahaan (Hernomo 2017). Banyaknya investor yang membeli saham perusahaan, maka akan menaikkan harga saham perusahaan sehingga nilai perusahaan akan meningkat pula. Prospek perusahaan yang baik akan tercermin dari profitabilitas yang tinggi, yang dapat memicu investor untuk ikut meningkatkan permintaan saham (Prasetyorini 2013). Nilai perusahaan yang tinggi tercermin dari nilai sahamnya yang tinggi. Nilai saham yang tinggi menunjukkan nilai pasar perusahaan yang tinggi (Ardiyanto and Haryanto 2017).

Penelitian mengenai pengaruh kinerja keuangan terhadap nilai perusahaan sudah pernah dilakukan oleh Muliani, Yuniarta, and Sinarwati (2014); Mudjijah, Khalid, and Astuti (2019) yang menyatakan bahwa kinerja keuangan berpengaruh terhadap nilai perusahaan, sehingga dapat diajukan hipotesis sebagai berikut:

$\mathrm{H}_{1}$ : kinerja keuangan berpengaruh terhadap nilai perusahaan.

\section{Kepemilikan Institusional, Kinerja Keuangan Dan Nilai Perusahaan}

Kepemilikan institusional merupakan presentase saham yang dimiliki investor institusi (Prastiwi and Walidah 2020). Berdasarkan stakeholder theory, keberadaan kepemilikan institusional dapat melakukan fungsi monitoring dan mencegah manajemen melakukan tindakan mementingkan diri sendiri untuk memperhatikan kepentingan stakeholder lainnya (Freeman 1984). Fungsi monitoring yang dilakukan diindikasikan mampu membuat manajemen lebih terbuka, salah satunya terbuka mengenai kinerja keuangan yang dilakukan perusahaan (Setiawan and Fitria 2015). Jumlah kepemilikan institusional menentukan kelangsungan perusahaan yang berpengaruh pada kinerja perusahaan dalam mencapai tujuan dengan memaksimalkan nilai keuangan perusahaan (Apriada and Suardikha 2016). Nilai perusahaan termasuk baik apabila kinerja keuangan yang dihasilkan baik (Sudibya and Restuti 2014).

Penelitian mengenai pengaruh kepemilikan institusional terhadap kinerja keuangan sudah pernah dilakukan oleh Hermiyetti and Katlanis (2014); Petta and 
Tarigan (2017) yang menemukan bahwa kepemilikan institusional berpengaruh terhadap kinerja keuangan. Penelitian mengenai pengaruh kepemilikan institusional terhadap nilai perusahaan sudah pernah dilakukan oleh Murwaningsari (2009); Sukirni (2012); Widyasari, Suhadak, and Husaini (2015); Apriada and Suardikha (2016); Mastuti and Prastiwi (2021) yang menemukan bahwa kepemilikan institusional berpengaruh terhadap nilai perusahaan. Sedangkan penelitian mengenai pengaruh kepemilikan institusional terhadap nilai perusahaan yang dimediasi oleh kinerja keuangan sudah pernah dilakukan oleh Mastuti and Prastiwi (2021) yang menemukan bahwa profitabilitas tidak mampu memediasi pengaruh kepemilikan institusional terhadap nilai perusahaan, sehingga dapat diajukan hipotesis sebagai berikut:

$\mathrm{H}_{2}$ : kepemilikan institusional berpengaruh terhadap kinerja keuangan.

$\mathrm{H}_{3}$ : kepemilikan institusional berpengaruh terhadap nilai perusahaan.

$\mathrm{H}_{4}$ : kepemilikan institusional tidak berpengaruh terhadap nilai perusahaan melalui kinerja keuangan.

\section{Ukuran Komite Audit, Kinerja Keuangan Dan Nilai Perusahaan}

Menurut stakeholder theory, besarnya ukuran komite audit dalam perusahaan diindikasikan dapat melakukan pengawasan terhadap manajemen (Freeman 1984). Fungsi pengawasan terhadap manajemen diindikasikan mampu membuat manajemen lebih terbuka mengenai kinerja keuangan perusahaan (Setiawan and Fitria 2015). Komite audit timbul sebagai akibat peran pengawasan dan akuntabilitas dewan komisaris perusahaan pada umumnya belum memadai (Surya and Yustiavandana 2006). Salah satu peran penting dari komite audit yaitu menjaga terciptanya sistem pengawasan perusahaan dalam memelihara kredibilitas proses penyusunan laporan keuangan perusahaan serta terlaksananya penerapan good corporate governance yang baik (Purbopangestu and Subowo 2014).

Komite audit bertugas untuk melakukan pengendalian terhadap laporan keuangan dengan melakukan pengawasan terhadap laporan keuangan, melakukan pengawasan terhadap audit eksternal, dan melakukan pengawasan terhadap audit internal, sehingga dengan adanya pengawasan akan laporan keuangan dan pengawasan terhadap audit eksternal tersebut maka sifat opportunistic manajemen yang dapat merugikan perusahaan dapat diminimalisir (Anugerah 2014). Secara tidak langsung hal-hal yang dapat mengurangi profitabilitas akan dapat terdeteksi dengan cepat dan ditanggulangi oleh perusahaan sedini mungkin, sehingga profitabilitas suatu perusahaan akan meningkat (Tjahjono and Chaeriyah 2017). Fungsi komite audit yang berjalan secara efektif dan efisien maka pengendalian terhadap perusahaan akan jauh lebih baik yang mengakibatkan konflik keagenan yang terjadi antara principle dan agent dapat diminimalisasi, sehingga akan meningkatkan kinerja perusahaan, yang pada akhirnya akan meningkatkan nilai tambah perusahaan (Julianti 2015). Meningkatnya kinerja perusahaan maka tingkat profitabilitas yang diperoleh perusahaan juga meningkat sehingga akan menarik minat para investor untuk berinvestasi pada perusahaan tersebut (Putra and Lestari 2016).

Penelitian mengenai pengaruh ukuran komite audit terhadap kinerja keuangan sudah pernah dilakukan oleh Prayanthi and Laurens (2020); Setyarini, Putra, and Nugraheni (2021) yang menemukan bahwa ukuran komite audit tidak 
berpengaruh terhadap kinerja keuangan. Penelitian mengenai pengaruh ukuran komite audit terhadap nilai perusahaan sudah pernah dilakukan oleh Widyasari, Suhadak, and Husaini (2015); Onasis (2016); Sukmono and Yadiati (2016) yang menemukan bahwa ukuran komite audit berpengaruh terhadap nilai perusahaan. Namun penelitian mengenai pengaruh ukuran komite audit terhadap nilai perusahaan yang dimediasi oleh kinerja keuangan belum ditemukan, sehingga dapat diajukan hipotesis sebagai berikut:

$\mathrm{H}_{5}$ : ukuran komite audit tidak berpengaruh terhadap kinerja keuangan.

$\mathrm{H}_{6}$ : ukuran komite audit berpengaruh terhadap nilai perusahaan.

$\mathrm{H}_{7}$ : ukuran komite audit berpengaruh terhadap nilai perusahaan melalui kinerja keuangan.

\section{Corporate Social Responsibility, Kinerja Keuangan Dan Nilai Perusahaan}

Kesenjangan sosial dan kerusakan lingkungan sekitar perusahaan dapat terjadi jika perusahaan hanya mengutamakan kepentingan pemilik modal saja (Lako 2014). Oleh karena itu, kesadaran dan kepedulian perusahaan terhadap lingkungan sekitarnya diperlukan melalui pengungkapan tanggung jawab sosial perusahaan (CSR) (Budiman 2015). Perusahaan melalui CSR akan berorientasi pada semua pihak yang berkepentingan tidak hanya kepada pemilik modal saja yaitu investor dan kreditor, tetapi juga kepada karyawan, konsumen, masyarakat dan pemerintah (Ghozali and Chariri 2014, 439). Image perusahaan akan semakin meningkat dengan semakin banyaknya bentuk pertanggungjawaban perusahaan terhadap lingkungannya (Meiyana and Aisyah 2019). Citra perusahaan yang baik di masyarakat akan membuat investor lebih berminat untuk berinvestasi dan loyalitas dari konsumen akan semakin tinggi, sehingga kedepan penjualan perusahaan akan membaik serta profitabilitas perusahaan juga meningkat (Susanto and Ardini 2016). Dengan profitabilitas yang meningkat maka kinerja perusahaan akan semakin baik yang pada akhirnya akan meningkatkan nilai perusahaan (Putra and Wiagustini 2013).

Penelitian mengenai pengaruh CSR terhadap kinerja keuangan sudah pernah dilakukan oleh Suciwati, Pradnyan, and Ardina (2017); Alkhairani, Kamaliah, and Rokhmawati (2020) yang menyatakan bahwa CSR berpengaruh terhadap kinerja keuangan. Penelitian mengenai pengaruh CSR terhadap nilai perusahaan sudah pernah dilakukan oleh Patmawati (2016); Susanto and Ardini (2016); Ardiyanto and Haryanto (2017) yang menemukan bahwa CSR berpengaruh terhadap nilai perusahaan. Sedangkan penelitian mengenai pengaruh CSR terhadap nilai perusahaan yang dimediasi oleh kinerja keuangan sudah pernah dilakukan oleh Alkhairani, Kamaliah, and Rokhmawati (2020) yang menemukan bahwa CSR berpengaruh terhadap nilai perusahaan yang dimediasi oleh profitabilitas, sehingga dapat diajukan hipotesis sebagai berikut:

$\mathrm{H}_{8}$ : CSR berpengaruh terhadap kinerja keuangan.

$\mathrm{H}_{9}$ : $C S R$ berpengaruh terhadap nilai perusahaan.

$\mathrm{H}_{10}$ : CSR berpengaruh terhadap nilai perusahaan melalui kinerja keuangan.

\section{METODE PENELITIAN}

Penelitian ini menggunakan metode kuantitatif deskriptif. Sumber data data penelitian menggunakan data sekunder berupa laporan tahunan perusahaan. 
Populasi dalam penelitian ini adalah perusahaan manufaktur yang terdaftar di BEI periode 2018-2020. Metode pengambilan sampel dengan menggunakan purposive sampling. Purposive sampling merupakan pengambilan sampel dari populasi berdasarkan kriteria tertentu (Hartono 2013, 98). Kriteria yang digunakan dalam penelitian ini adalah: (1) Perusahaan manufaktur yang terdaftar berturut-turut di BEI periode 2018-2020. (2) Perusahaan manufaktur yang secara terus menerus menerbitkan laporan tahunan periode 2018-2020. (3) Perusahaan manufaktur yang memperoleh laba periode 2018-2020. (4) Perusahaan manufaktur yang mengungkapkan data yang dibutuhkan terkait kepemilikan institusional, ukuran komite audit, CSR, ROA dan nilai perusahaan periode 2018-2020. (5) Perusahaan manufaktur yang menerbitkan laporan tahunan dalam bentuk mata uang rupiah periode 2018-2020. Berdasarkan kriteria tersebut diperoleh jumlah sampel sebanyak 74 perusahaan selama periode 2018-2020, sehingga diperoleh data sampel sebanyak 222.

Variabel dependen dalam penelitian ini adalah nilai perusahaan. Nilai perusahaan diukur dengan menggunakan price book value $(P B V)$. $P B V$ digunakan sebagai proksi, karena bagi investor $P B V$ merupakan hal yang sangat penting dalam menentukan strategi dalam berinvestasi di pasar modal. Variabel intervening dalam penelitian ini adalah kinerja keuangan. Dalam penelitian ini kinerja keuangan diukur dengan menggunakan rasio ROA. Sedangkan variabel independen pada penelitian ini adalah kepemilikan institusional, ukuran komite audit dan CSR. Kepemilikan institusional diukur dengan jumlah saham beredar yang dimiliki institusional dibagi dengan jumlah saham yang beredar. Ukuran komite audit diukur dengan jumlah anggota komite audit. CSR diukur dengan indeks CSR dengan menggunakan metode content analysis dan variabel dummy, jika mengungkap diberi nilai satu tiap komponen dan jika tidak mengungkap diberi nilai nol, selanjutnya, skor dari setiap item dijumlahkan untuk memperoleh keseluruhan skor untuk setiap perusahaan. Teknik analisis data menggunakan analisis jalur.

\section{HASIL DAN PEMBAHASAN PENELITIAN}

\section{Statistik Deskriptif}

Tabel 1. Hasil Statistik Deskriptif

\begin{tabular}{lccccc}
\hline Variable & $\boldsymbol{N}$ & Minimum & Maximum & Mean & Std. Deviation \\
\hline$P B V$ & 222 & 0,053 & 5,664 & 1,36510 & 1,235152 \\
INS & 222 & 27,75 & 98,24 & 71,7376 & 16,70756 \\
KOM & 222 & 3,00 & 5,00 & 3,1275 & 0,41438 \\
$C S R$ & 222 & 0,0549 & 0,8571 & 0,222579 & 0,2028548 \\
ROA & 222 & 3,080 & 4,178 & 0,22058 & 0,488653 \\
\hline
\end{tabular}

$P B V$ : nilai perusahaan; INS: kepemilikan institusional; KOM: ukuran komite audit; CSR: corporate social responsibility; ROA: kinerja keuangan.

Sumber: data sekunder (diolah)

Berdasarkan Tabel 1, disajikan hasil statistik deskriptif untuk melihat nilai minimum, maximum, mean (rata-rata), dan standard deviation dari data penelitian. Nilai perusahaan memiliki nilai minimum sebesar 0,053, nilai maksimum sebesar 5,664, nilai rata-rata sebesar 1,36510 dan nilai standar deviasi sebesar 1,235152. 
Kepemilikan institusional memiliki nilai minimum sebesar 27,75 , nilai maksimum sebesar 98,24, nilai rata-rata sebesar 71,7376 dan nilai standar deviasi sebesar 16,70756. Ukuran komite audit memiliki nilai minimum sebesar 3,00, nilai maksimum sebesar 5,00, nilai rata-rata sebesar 3,1275 dan nilai standar deviasi sebesar 0,41438. CSR memiliki nilai minimum sebesar 0,0549, nilai maksimum sebesar 0,8571, nilai rata-rata sebesar 0,222579 dan nilai standar deviasi sebesar 0,2028548. ROA memiliki nilai minimum sebesar 3,080, nilai maksimum sebesar 4,178 , nilai rata-rata sebesar 0,22058 dan nilai standar deviasi sebesar 0,488653 .

\section{Hasil Analisis Jalur}

Tabel 2. Hasil Analisis Jalur I

\begin{tabular}{lcc}
\hline Variable & Coefisient Path & Significant \\
\hline INS $\rightarrow$ ROA & $-0,001$ & 0,255 \\
KOM $\rightarrow$ ROA & 0,185 & 0,104 \\
CSR $\rightarrow$ ROA & 0,324 & 0,004 \\
\hline \multicolumn{2}{l}{ Sumber: data sekunder (diolah) }
\end{tabular}

Tabel 2 memperlihatkan hasil analisis jalur I dari kepemilikan institusional, ukuran komite audit dan CSR terhadap kinerja keuangan. Kepemilikan institusional memiliki nilai koefisien sebesar -0,001 (negatif) dan signifikansi sebesar 0,255 terhadap kinerja keuangan, dimana nilai signifikansi > $0,05(0,255>0,05)$. Sehingga hipotesis yang menyatakan kepemilikan institusional memiliki pengaruh terhadap kinerja keuangan tidak terbukti kebenarannya $\left(\mathrm{H}_{2}\right.$ ditolak). Ukuran komite audit memiliki nilai koefisien sebesar 0,185 (positif) dan signifikansi sebesar 0,104 terhadap kinerja keuangan, dimana nilai signifikansi $>0,05(0,104>0,05)$. Sehingga hipotesis yang menyatakan ukuran komite audit tidak memiliki pengaruh terhadap kinerja keuangan terbukti kebenarannya $\left(\mathrm{H}_{5}\right.$ diterima). $C S R$ memiliki nilai koefisien sebesar 0,324 (positif) dan nilai signifikansi sebesar 0,004 terhadap kinerja keuangan, dimana nilai signifikansi $<0,05(0,004<0,05)$. Sehingga hipotesis yang menyatakan CSR memiliki pengaruh terhadap kinerja keuangan terbukti kebenarannya $\left(\mathrm{H}_{8}\right.$ diterima).

Tabel 3. Hasil Analisis Jalur II

\begin{tabular}{lcc}
\hline \multicolumn{1}{c}{ Variable } & Coefisient Path & Significant \\
\hline INS $\rightarrow P B V$ & 0,006 & 0,005 \\
KOM $\rightarrow P B V$ & 0,402 & 0,012 \\
$C S R \rightarrow P B V$ & 0,306 & 0,672 \\
$R O A \rightarrow P B V$ & 1,605 & 0,044 \\
\hline
\end{tabular}

Sumber: data sekunder (diolah)

Tabel 3 memperlihatkan hasil analisis jalur II dari kepemilikan institusional, ukuran komite audit, CSR dan kinerja keuangan terhadap nilai perusahaan. Kepemilikan institusional memiliki nilai koefisien sebesar 0,006 (positif) dan nilai signifikansi sebesar 0,005 terhadap nilai perusahaan, dimana nilai signifikansi $<0,05(0,005<0,05)$. Sehingga hipotesis yang menyatakan kepemilikan institusional memiliki pengaruh terhadap nilai perusahaan terbukti 
kebenarannya $\left(\mathrm{H}_{3}\right.$ diterima). Ukuran komite audit memiliki nilai koefisien sebesar 0,402 (positif) dan nilai signifikansi sebesar 0,012 terhadap nilai perusahaan, dimana nilai signifikansi $<0,05(0,012<0,05)$. Sehingga hipotesis yang menyatakan ukuran komite audit memiliki pengaruh terhadap nilai perusahaan terbukti kebenarannya ( $\mathrm{H}_{6}$ diterima). $C S R$ memiliki nilai koefisien sebesar 0,306 (positif) dan nilai signifikansi sebesar 0,672 terhadap nilai perusahaan, dimana nilai signifikansi $>0,05(0,672>0,05)$. Sehingga hipotesis yang menyatakan $C S R$ memiliki pengaruh terhadap nilai perusahaan tidak terbukti kebenarannya $\left(\mathrm{H}_{9}\right.$ ditolak). Kinerja keuangan memiliki nilai koefisien sebesar 1,605 (positif) dan nilai signifikansi sebesar 0,044 terhadap nilai perusahaan, dimana nilai signifikansi $<0,05(0,044<0,05)$. Sehingga hipotesis yang menyatakan kinerja keuangan memiliki pengaruh terhadap nilai perusahaan terbukti kebenarannya $\left(\mathrm{H}_{1}\right.$ diterima).

\section{Hasil Uji Sobel}

Tabel 4. Hasil Uji Sobel

\begin{tabular}{lcc}
\hline \multicolumn{1}{c}{ Variable } & $\mathbf{t}_{\text {hitung }}$ & $\mathbf{t}_{\text {tabel }}$ \\
\hline $\mathrm{INS} \rightarrow \mathrm{ROA} \rightarrow \mathrm{PBV}$ & $-0,986$ & 1,9707 \\
$\mathrm{KOM} \rightarrow R O A \rightarrow P B V$ & 3,1727 & 1,9707 \\
$C S R \rightarrow R O A \rightarrow P B V$ & 2,1221 & 1,9707 \\
\hline Sumber: data sekunder (diolah) & &
\end{tabular}

Pengujian hipotesis mediasi (intervening) dapat dilakukan dengan prosedur yang dikembangkan oleh Sobel (1982) dan dikenal dengan uji Sobel. Pengambilan keputusan dengan cara membandingkan nilai $t_{\text {hitung }}$ dengan $t_{\text {tabel }}$, jika nilai $t_{\text {hitung }}$ lebih besar dari nilai $t_{\text {tabel }}$ maka dapat dikatakan bahwa terjadi pengaruh mediasi, sebaliknya tidak terjadi pengaruh. Tabel 4 memperlihatkan hasil uji Sobel dari kepemilikan institusional, ukuran komite audit, dan CSR terhadap nilai perusahaan yang dimediasi oleh kinerja keuangan. Kepemilikan institusional memiliki nilai $t_{\text {hitung }}$ sebesar $-0,986$ terhadap nilai perusahaan melalui kinerja keuangan, berarti $t_{\text {hitung }}<t_{\text {tabel }}(-0,986<1,9707)$. Sehingga hipotesis yang menyatakan kepemilikan institusional tidak memiliki pengaruh terhadap nilai perusahaan melalui kinerja keuangan terbukti kebenarannya $\left(\mathrm{H}_{4}\right.$ diterima). Ukuran komite audit memiliki nilai $t_{\text {hitung }}$ sebesar 3,1727 terhadap nilai perusahaan melalui kinerja keuangan, berarti $t_{\text {hitung }}>t_{\text {tabel }}(3,1727<1,9707)$. Sehingga hipotesis yang menyatakan ukuran komite audit memiliki pengaruh terhadap nilai perusahaan melalui kinerja keuangan terbukti kebenarannya $\left(\mathrm{H}_{7}\right.$ diterima). $C S R$ memiliki nilai $\mathrm{t}_{\text {hitung }}$ sebesar 2,1221 terhadap nilai perusahaan melalui kinerja keuangan, berarti $\mathrm{t}_{\text {hitung }}>\mathrm{t}_{\text {tabel }}(2,1221<1,9707)$. Sehingga hipotesis yang menyatakan CSR memiliki pengaruh terhadap nilai perusahaan melalui kinerja keuangan terbukti kebenarannya ( $\mathrm{H}_{10}$ diterima).

\section{Koefisien Determinasi}

Tabel 5 memperlihatkan bahwa untuk jalur I nilai $R$ Square sebesar 0,319 $(31,9 \%)$, berarti secara simultan kepemilikan institusional, ukuran komite audit dan $C S R$ terhadap kinerja keuangan berpengaruh sebesar 31,9\%. Jalur II nilai $R$ Square sebesar 0,615 (61,5\%), berarti secara simultan kepemilikan institusional, 
ukuran komite audit, $C S R$ dan kinerja keuangan terhadap nilai perusahaan berpengaruh sebesar $61,5 \%$. Sedangkan nilai $R^{2} m$ sebesar $0,738(73,8 \%)$, berarti keragaman data yang dapat dijelaskan oleh model dalam penelitian ini adalah sebesar $73,8 \%$, sedangkan sisanya sebesar $26,2 \%$ dijelaskan oleh faktor lain diluar model ini.

Tabel 5. Koefisien Determinasi

\begin{tabular}{cccc}
\hline Jalur & $\boldsymbol{R}$-Square & Error & $\boldsymbol{R}^{2} \boldsymbol{m}$ \\
\hline I & 0,319 & 0,825 & \multirow{2}{*}{0,738} \\
II & 0,615 & 0,620 & \\
\hline
\end{tabular}

Sumber: data sekunder (diolah)

\section{Pengaruh Kinerja Keuangan Terhadap Nilai Perusahaan}

Hasil hipotesis $\mathrm{H}_{1}$ diterima, berarti kinerja keuangan berpengaruh signifikan terhadap nilai perusahaan. Nilai koefisien kinerja keuangan menunjukkan nilai positif terhadap nilai perusahaan, sehingga kinerja keuangan berpengaruh positif dan signifikan terhadap nilai perusahaan. Hal tersebut mengindikasikan bahwa jika kinerja keuangan perusahaan baik maka nilai perusahaan juga akan baik. Hasil penelitian ini didukung oleh penelitian Muliani, Yuniarta, and Sinarwati (2014); Mudjijah, Khalid, and Astuti (2019) yang menemukan bahwa kinerja keuangan berpengaruh terhadap nilai perusahaan. Namun bertolak belakang dengan penelitian yang dilakukan oleh Hermawan and Maf'ulah (2014) yang menemukan bahwa kinerja keuangan tidak berpengaruh terhadap nilai perusahaan.

\section{Pengaruh Kepemilikan Institusional Terhadap Kinerja Keuangan}

Hasil hipotesis $\mathrm{H}_{2}$ ditolak, berarti kepemilikan institusional tidak berpengaruh terhadap kinerja keuangan. Hasil temuan ini mengindikasikan bahwa kepemilikan institusional tidak dapat menentukan kinerja keuangan perusahaaan. Hasil penelitian ini didukung oleh penelitian Laksana (2015) yang menemukan bahwa kepemilikan institusional tidak berpengaruh signifikan terhadap kinerja keuangan. Namun bertolak belakang dengan penelitian yang dilakukan oleh Hermiyetti and Katlanis (2014); Petta and Tarigan (2017) yang menemukan bahwa kepemilikan institusional berpengaruh terhadap kinerja keuangan.

\section{Pengaruh Kepemilikan Institusional Terhadap Nilai Perusahaan}

Hasil hipotesis $\mathrm{H}_{3}$ diterima, berarti kepemilikan institusional berpengaruh signifikan terhadap nilai perusahaan. Nilai koefisien kepemilikan institusional menunjukkan nilai positif terhadap nilai perusahaan, sehingga kepemilikan institusional berpengaruh positif dan signifikan terhadap nilai perusahaan. Hal ini mengindikasikan bahwa semakin banyak kepemilikan institusional maka nilai perusahaan akan menjadi lebih baik. Hasil penelitian ini didukung oleh penelitian Murwaningsari (2009); Sukirni (2012); Widyasari, Suhadak, and Husaini (2015); Apriada and Suardikha (2016); Mastuti and Prastiwi (2021) yang membuktikan bahwa kepemilikan institusional berpengaruh positif terhadap nilai perusahaan. Akan tetapi bertolak belakang dengan penelitian yang dilakukan oleh Adnantara (2013); Purbopangestu and Subowo (2014); Susanti and Mildawati (2014); Mukhtaruddin, Relasari, and Felmania (2014); Bilayudha and Kiswanto (2015) 
yang menemukan bukti bahwa kepemilikan institusional tidak berpengaruh terhadap nilai perusahaan.

\section{Pengaruh Kepemilikan Institusional Terhadap Nilai Perusahaan Melalui Kinerja Keuangan}

Hasil hipotesis $\mathrm{H}_{4}$ diterima, berarti kepemilikan institusional tidak berpengaruh terhadap nilai perusahaan melalui kinerja keuangan. Semakin besar proporsi kepemilikan institusional dalam perusahaan, maka semakin besar peran institusional dalam memonitor manajer namun pengawasan ini ternyata tidak mendorong manajer untuk meningkatkan kinerjanya. Hal ini mengindikasikan bahwa kepemilikan institusional tidak dapat menentukan kinerja keuangan perusahaaan sehingga tidak ada pengaruh terhadap nilai perusahaan. Hasil penelitian ini didukung oleh Wardani and Hermuningsih (2011); Mastuti and Prastiwi (2021) yang menemukan bahwa bahwa kinerja keuangan tidak mampu memediasi pengaruh kepemilikan institusional terhadap nilai perusahaan.

\section{Pengaruh Ukuran Komite Audit Terhadap Kinerja Keuangan}

Hasil hipotesis $\mathrm{H}_{5}$ diterima, berarti ukuran komite audit tidak berpengaruh terhadap kinerja keuangan. Hal ini mengindikasikan bahwa dengan adanya komite audit tidak dapat mempengaruhi kinerja keuangan perusahaan. Sebab dengan ukuran komite audit yang banyak atau sedikit, tetap komite audit bertugas untuk melakukan pengawasan terhadap laporan keuangan bukan untuk meningkatkan kinerja keuangan. Hasil penelitian ini didukung oleh penelitian Prayanthi and Laurens (2020); Setyarini, Putra, and Nugraheni (2021) yang menemukan bahwa ukuran komite audit tidak berpengaruh terhadap kinerja keuangan.

\section{Pengaruh Ukuran Komite Audit Terhadap Nilai Perusahaan}

Hasil hipotesis $\mathrm{H}_{6}$ diterima, berarti ukuran komite audit berpengaruh signifikan terhadap nilai perusahaan. Nilai koefisien ukuran komite audit memiliki nilai positif terhadap nilai perusahaan, sehingga ukuran komite audit berpengaruh positif dan signifikan terhadap nilai perusahaan. Hal ini mengindikasikan bahwa semakin besar ukuran komite audit maka akan meningkatkan nilai perusahaan. Besarnya ukuran komite audit dalam perusahaan dapat melakukan pengawasan terhadap perusahaan sehingga dapat menaikkan nilai perusahaan. Hasil penelitian ini didukung oleh penelitian Widyasari, Suhadak, and Husaini (2015); Onasis (2016); Sukmono and Yadiati (2016) yang menemukan bahwa ukuran komite audit berpengaruh terhadap nilai perusahaan. Namun bertolak belakang dengan penelitian yang dilakukan oleh Mukhtaruddin, Relasari, and Felmania (2014); Purbopangestu and Subowo (2014); Bilayudha and Kiswanto (2015) yang menemukan bahwa ukuran komite audit tidak berpengaruh terhadap nilai perusahaan.

\section{Pengaruh Ukuran Komite Audit Terhadap Nilai Perusahaan Melalui Kinerja Keuangan}

Hasil hipotesis $\mathrm{H}_{7}$ diterima, berarti menyatakan ukuran komite audit berpengaruh terhadap nilai perusahaan melalui kinerja keuangan. Komite audit bertugas dalam melakukan pengendalian terhadap laporan keuangan dengan mengawasi laporan keuangan, mengawasi audit eksternal, dan mengawasi audit 
internal. Adanya pengawasan tersebut maka sifat opportunistic manajemen yang dapat merugikan perusahaan dapat diminimalisir sehingga dapat meningkat nilai perusahaan.

\section{Pengaruh Corporate Social Responsibility Terhadap Kinerja Keuangan}

Hasil hipotesis $\mathrm{H}_{8}$ diterima, $C S R$ berpengaruh signifikan terhadap kinerja keuangan. Nilai koefisien $C S R$ menunjukkan nilai positif terhadap kinerja keuangan, sehingga $C S R$ berpengaruh positif dan signifikan terhadap kinerja keuangan. Hal ini mengindikasikan bahwa semakin baik $C S R$ perusahaan maka dapat meningkatkan kinerja keuangan perusahaan. Hasil penelitian ini didukung oleh penelitian Suciwati, Pradnyan, and Ardina (2017); Alkhairani, Kamaliah, and Rokhmawati (2020) yang menemukan bahwa CSR berpengaruh terhadap kinerja keuangan. Namun bertolak belakang dengan penelitian yang dilakukan oleh Djazilah and Kurnia (2016) yang menemukan bahwa CSR tidak berpengaruh terhadap kinerja keuangan.

\section{Pengaruh Corporate Social Responsibility Terhadap Nilai Perusahaan}

Hasil hipotesis $\mathrm{H}_{9}$ ditolak, berarti $C S R$ tidak berpengaruh terhadap nilai perusahaan. Hal ini mengindikasikan bahwa pengungkapan $C S R$ memberikan manfaat yang signifikan dalam jangka panjang, namun tidak untuk jangka waktu pendek, karena investor di Indonesia lebih cenderung melakukan jual beli saham harian atau jangka pendek dan kurang memperhatikan keberlangsungan jangka panjang perusahaan. Oleh sebab itu CSR tidak dapat mempengaruhi nilai perusahaan. Hasil penelitian ini didukung oleh Alkhairani, Kamaliah, and Rokhmawati (2020) yang menemukan bahwa CSR tidak berpengaruh terhadap nilai perusahaan. Namun bertolak belakang dengan penelitian yang dilakukan oleh Patmawati (2016); Susanto and Ardini (2016); Ardiyanto and Haryanto (2017); yang menemukan bahwa $C S R$ berpengaruh terhadap nilai perusahaan.

\section{Pengaruh Corporate Social Responsibility Terhadap Nilai Perusahaan Melalui Kinerja Keuangan}

Hasil hipotesis H10 diterima, berarti CSR berpengaruh terhadap nilai perusahaan melalui kinerja keuangan. Hal ini mengindikasikan bahwa semakin tinggi pengungkapan $C S R$ maka perusahaan semakin dipandang bertanggung jawab, sehingga memperoleh legitimasi dari masyarakat yang kemudian mampu memberikan kontribusi dalam peningkatan kinerja keuangan perusahaan dan secara tidak langsung akan meningkatkan nilai perusahaan. Hasil penelitian ini didukung oleh penelitian Alkhairani, Kamaliah, and Rokhmawati (2020) yang menemukan bahwa $C S R$ berpengaruh terhadap nilai perusahaan yang dimediasi oleh profitabilitas.

\section{KESIMPULAN}

Kinerja keuangan berpengaruh positif dan signifikan terhadap nilai perusahaan. Kepemilikan institusional tidak berpengaruh terhadap kinerja keuangan. Ukuran komite audit tidak berpengaruh terhadap kinerja keuangan. $C S R$ berpengaruh positif dan signifikan terhadap kinerja keuangan. Kepemilikan institusional berpengaruh positif dan signifikan terhadap nilai perusahaan. Ukuran 
komite audit berpengaruh positif dan signifikan terhadap nilai perusahaan. CSR tidak berpengaruh terhadap nilai perusahaan. Kepemilikan institusional tidak berpengaruh terhadap nilai perusahaan melalui kinerja keuangan. Ukuran komite audit berpengaruh terhadap nilai perusahaan melalui kinerja keuangan. CSR berpengaruh terhadap nilai perusahaan melalui kinerja keuangan.

Hasil penelitian ini dapat dimanfaatkan dan menjadi acuan bagi manajemen dan investor dalam mengembangkan perusahaan dan menanam modal. Penelitian ini memiliki keterbatasan yaitu mengenai variabel, data dan jangka waktu. Oleh sebab itu penelitian lanjutan diperlukan dengan menambahkan variabel-variabel selain variabel dalam penelitian ini, karena masih ada ruang sebesar 26,2\%. Kemudian rentang waktu penelitian diperpanjang dan jumlah sampel ditambah sehingga dapat memperbesar jumlah data dan mewakili data perusahaan yang ada.

\section{DAFTAR PUSTAKA}

Adnantara, Komang Fridagustina. 2013. "Pengaruh Struktur Kepemilikan Saham dan Corporate Social Responsibility Pada Nilai Perusahaan." Buletin Studi Ekonomi 18 (2): 107-113. https://ojs.unud.ac.id/index.php/bse/article/view/7787.

Alkhairani, Alkhairani, Kamaliah Kamaliah, and Andewi Rokhmawati. 2020. "Analisis Pengaruh Good Corporate Governance (GCG) dan Corporate Social Responsibility (CSR) Terhadap Nilai Perusahaan Dengan Profitabilitas Sebagai Variabel Intervening pada Perusahaan Pertambangan yang Terdaftar di Bursa Efek Indonesia.” Jurnal Ekonomi Kiat 31 (2): 1025. https://journal.uir.ac.id/index.php/kiat/article/view/2783.

Anugerah, Rita. 2014. "Peranan Good Corporate Governance Dalam Pencegahan Fraud." Jurnal Akuntansi: Media Riset Akuntansi \& Keuangan 3 (1): 101-113. https://ja.ejournal.unri.ac.id/index.php/JA/article/view/2538.

Apriada, Kadek, and Made Sadha Suardikha. 2016. "Pengaruh Struktur Kepemilikan Saham, Struktur Modal dan Profitabilitas Pada Nilai Perusahaan." E-Jurnal Ekonomi dan Bisnis Universitas Udayana 5 (2): 201-218. https://ojs.unud.ac.id/index.php/EEB/article/view/9309.

Ardiyanto, Taufan, and Haryanto Haryanto. 2017. "Pengaruh Pengungkapan Corporate Social Responsibility Terhadap Nilai Perusahaan Dengan Kinerja Keuangan Sebagai Variabel Intervening." Diponegoro Journal of Accounting 6 337-351. https://ejournal3.undip.ac.id/index.php/accounting/article/view/18687.

Bilayudha, Falah, and Kiswanto Kiswanto. 2015. "Determinan Nilai Perusahaan Pada Perusahaan Pertambangan Yang Terdaftar Di BEI." Accounting $\begin{array}{lllll}\text { Analysis } & \text { Journal } & 4 & \text { (3): }\end{array}$ https://journal.unnes.ac.id/sju/index.php/aaj/article/view/8312.

Budiman, Nita Andriyani. 2015. "Faktor-Faktor Yang Mempengaruhi Pengungkapan Tanggung Jawab Sosial Perusahaan." JRAMB: Jurnal Riset $\begin{array}{lllll}\text { Akuntansi } & \text { Mercu } & \text { Buana } & 1 & \text { (1): }\end{array}$ https://doi.org/10.26486/jramb.v1i1.9. 
Djazilah, Rachma, and Kurnia Kurnia. 2016. "Pengaruh Mekanisme GCG Dan Pengungkapan CSR Terhadap Kinerja Keuangan." Jurnal Ilmu dan Riset $\begin{array}{lllll}\text { Akuntansi } & \text { (JIRA) } & 5 & \text { (10): }\end{array}$ http://jurnalmahasiswa.stiesia.ac.id/index.php/jira/article/view/2435.

Fawaid, Muhammad Izzul. 2017. Pengaruh Good Corporate Governance Terhadap Nilai Perusahaan dengan Kinerja Keuangan Sebagai Variabel Moderating (Studi Kasus pada Perusahaan yang Terdaftar di CGPI Tahun 2011-2015). Skripsi Fakultas Ekonomi Universitas Islam Negeri Maulana Malik Ibrahim. http://etheses.uin-malang.ac.id/5932/.

Freeman, R. Edward. 1984. Stakeholder Management: Framework And Philosophy. Pitman.

Ghozali, Imam, and Anis Chariri. 2014. Teori Akuntansi International Financial Reporting System (IFRS) Edisi 4. Semarang: Badan Penerbit Universitas Diponegoro.

Hartono, Jogiyanto. 2013. Metodologi Penelitian Bisnis: Salah Kaprah dan Pengalaman Pengalaman (Edisi 6). Yogyakarta: BPFE.

Hermawan, Sigit, and Afiyah Nurul Maf'ulah. 2014. "Pengaruh Kinerja Keuangan terhadap Nilai Perusahaan dengan Pengungkapan Corporate Social Responsibility sebagai Variabel Pemoderasi." Jurnal Dinamika Akuntansi 6 103-118.

https://journal.unnes.ac.id/nju/index.php/jda/article/view/3250.

Hermiyetti, Hermiyetti, and Erlinda Katlanis. 2014. "Analisis Pengaruh Kepemilikan Manajerial, Kepemilikan Institusional, Kepemilikan Asing, Dan Komite Audit Terhadap Kinerja Keuangan Perusahaan." Media Riset $\begin{array}{llll}\text { Akuntansi } & 4 & \text { (2): }\end{array}$ http://journal.bakrie.ac.id/index.php/journal_MRA/article/view/1723.

Hernomo, Michael. 2017. "Pengaruh Profitabilitas, Leverage, dan Kebijakan Dividen terhadap Nilai Perusahaan." Petra Business and Management Review $\quad 3 \quad$ (1): 1-11. http://publication.petra.ac.id/index.php/breview/article/view/9177.

Jensen, Michael C., and William Meckeling. 1976. Theory of The Firm. Repinted Harvard University Press.

Julianti, Defy Kurnia. 2015. Pengaruh Mekanisme Good Corporate Governance Terhadap Nilai Perusahaan Dengan Profitabilitas Sebagai Variabel Intervening Pada Perusahaan Manufaktur Yang Terdaftar Di Bursa Efek Indonesia Tahun 2010-2013. Skripsi Universitas Negeri Semarang.

Kemenperin. 2017. Industri Manufaktur Masuk Fase Pertumbuhan Kembali. Kementerian Perindustrian. https://www.kemenperin.go.id/artikel/17517/.

Kemenperin. 2021. Sektor Manufaktur Tumbuh Agresif di Tengah Tekanan Pandemi. Kementerian Perindustrian. https://kemenperin.go.id/artikel/22681/.

Lako, Andreas. 2014. Green Economy: Menghijaukan Ekonomi, Bisnis, \& Akuntansi. Jakarta: Erlangga.

Laksana, Jaya. 2015. "Corporate Governance Dan Kinerja Keuangan (Studi Kasus Pada Perusahaan Perbankan Yang Terdaftar Di Bei Periode 2008-2012)." E-Jurnal Akuntansi $11 \quad$ (1): 269-288. https://ojs.unud.ac.id/index.php/akuntansi/article/view/10545. 
Liu, Xiang, and Chen Zhang. 2017. "Coroporate Governance, Social Responsibility Information Disclosure, and Enterprise Value in China." Journal of Cleaner Production 142 (2): 1075-1084. https://doi.org/10.1016/j.jclepro.2016.09.102.

Mastuti, Alda Nadya, and Dewi Prastiwi. 2021. "Pengaruh Kepemilikan Institusional Dan Ukuran Dewan Terhadap Nilai Perusahaan Melalui Profitabilitas." Jurnal Penelitian Teori \& Terapan Akuntansi (PETA) 6 (2): 222-238. https://doi.org/10.51289/peta.v6i2.501.

Meiyana, Aida, and Mimin Nur Aisyah. 2019. "Pengaruh Kinerja Lingkungan, Biaya Lingkungan, Dan Ukuran Perusahaan Terhadap Kinerja Keuangan Dengan Corporate Social Responsibility Sebagai Variabel Intervening." NOMINAL: Barometer Riset Akuntansi Dan Manajemen 8 (1): 1-18. https://doi.org/10.21831/nominal.v8i1.24495.

Mudjijah, Slamet, Zulvia Khalid, and Diah Ayu Sekar Astuti. 2019. "Pengaruh Kinerja Keuangan Dan Struktur Modal Terhadap Nilai Perusahaan Yang Dimoderasi Variabel Ukuran Perusahaan." Jurnal Akuntansi dan Keuangan $\quad 8 \quad$ (1): 41-56. https://journal.budiluhur.ac.id/index.php/akeu/article/view/839.

Muliani, Luh Eni, Gede Adi Yuniarta, and Ni Kadek Sinarwati. 2014. "Pengaruh Kinerja Keuangan Terhadap Nilai Perusahaan Dengan Pengungkapan Corporate Social Responcibility Dan Good Corporate Governance Sebagai Variabel Pemoderasi." Jurnal Ilmiah Mahasiswa Akuntansi Undiksha 2 (1): 1-10. https://ejournal.undiksha.ac.id/index.php/S1ak/article/view/3423 Mukhtaruddin, Mukhtaruddin, Relasari Relasari, and Messa Felmania. 2014. "Good Corporate Governance Mechanism, Corporate Social Responsibility Disclosure on Firm Value: Empirical Study on Listed Company in Indonesia Stock Exchange." International Journal of Finance \& Accounting $\quad$ Studies 2 (1): 1-10. http://www.journals.aiac.org.au/index.php/IJFAS/article/view/467.

Murwaningsari, Etty. 2009. "Hubungan Corporate Governance, Corporate Social Responsibilites dan Corporate Financial Perfomance Dalam Satu Continuum." Jurnal Akuntansi dan Keuangan 11 (1): 30-41. https://jurnalakuntansi.petra.ac.id/index.php/aku/article/view/17864.

Nugroho, Mirza Nurdin, and Agung Yulianto. 2015. "Pengaruh Profitabilitas dan Mekanisme Corporate Governance Terhadap Pengungkapan CSR Perusahaan Terdaftar JII 2011-2013.” Accounting Analysis Journal 4 (1): 1-12. https://journal.unnes.ac.id/sju/index.php/aaj/article/view/7829.

Onasis, Kristie, and Robin Robin. 2016. "Pengaruh Tata Kelola Perusahaan Terhadap Nilai Perusahaan Pada Perusahaan Sektor Keuangan Yang Terdaftar di BEI." Bina Ekonomi 20 (1): 1-22. https://journal.unpar.ac.id/index.php/BinaEkonomi/article/view/1893.

Padmayanti, Ni Putu Enny Widhi, Ni Nyoman Ayu Suryandari, and I.A. Budhananda Munidewi. 2019. "Pengaruh Kinerja Keuangan Terhadap Nilai Perusahaan Dengan Dewan Komisaris Independen Sebagai Variabel Pemoderasi Pada Perusahaan Manufaktur Yang Terdaftar Di Bursa Efek Indonesia." Jurnal Riset Akuntansi (JUARA) 9 (1): 62-72. http://ejournal.unmas.ac.id/index.php/juara/article/view/303. 
Patmawati, Patmawati, 2017. "Pengaruh Corporate Social Responsibility Disclosure dan Good Corporate Governance Terhadap Nilai Perusahaan Dengan Kinerja Keuangan Sebagai Variabel Intervening." Jurnal Ilmiah Ekonomi Global Masa Kini $8 \quad$ (1): $48-58$. http://ejournal.uigm.ac.id/index.php/EGMK/article/view/245.

Petta, Brigitta Clarabella, and Josua Tarigan. 2017. "Pengaruh Kepemilikan Institusional Terhadap Kinerja Keuangan Melalui Struktur Modal Sebagai Variabel Intervening Pada Perusahaan Manufaktur Yang Terdaftar Dalam Bursa Efek Indonesia." Business Accounting Review 5 (2): 625-636. http://publication.petra.ac.id/index.php/akuntansi-bisnis/article/view/6638.

Prasetyorini, Bhekti Fitri Fitri. 2013. "Pengaruh Ukuran Perusahaan, Leverage, Price Earning Ratio dan Profitabilitas terhadap Nilai Perusahaan." Jurnal Ilmu Manajemen (JIM) 1 (1): 183-196. https://ejournal.unesa.ac.id/index.php/jim/article/view/1505.

Prastiwi, Dewi, and Alifiah Walidah. 2020. "Pengaruh Agresivitas Pajak Terhadap Nilai Perusahaan: Efek Moderasi Transparansi Dan Kepemilikan Institusional". Jurnal Ekonomi Dan Bisnis 23 (2): 203-224. https://doi.org/10.24914/jeb.v23i2.2997.

Prayanthi, Ika, and Christine Natalia Laurens. 2020. "Pengaruh Dewan Direksi, Komisaris Independen, Dan Komite Audit Terhadap Kinerja Keuangan Pada Sektor Makanan Dan Minuman.” Klabat Journal of Management 1 (1): 66-89. https://doi.org/10.31154/kjm.v1i1.450.66-89.

Purbopangestu, Hary Wisnu, and Subowo Subowo. 2014. "Pengaruh Good Corporate Governance Terhadap Nilai Perusahaan Dengan Corporate Social Responsibility Sebagai Variabel Intervening." Accounting Analysis $\begin{array}{llll}\text { Journal (3): 321-333. } & \text { 3 }\end{array}$ https://journal.unnes.ac.id/sju/index.php/aaj/article/view/4202.

Putra, A. A. Ngurah Dharma Adi, and Putu Vivi Lestari. 2016. "Pengaruh Kebijakan Dividen, Likuiditas, Profitabilitas Dan Ukuran Perusahaan Terhadap Nilai Perusahaan." E-Jurnal Manajemen 5 (7): 4044-4070. https://ojs.unud.ac.id/index.php/Manajemen/article/view/20373/.

Putra, Y. Yudha Dharma, and Ni Luh Putu Wiagustini. 2013. "Pengaruh Likuiditas Dan Leverage Terhadap Profitabilitas Dan Nilai Perusahaan Pada Perusahaan Perbankan Di BEI." JWM (Jurnal Wawasan Manajemen) 1 (2). https://jwm.ulm.ac.id/id/index.php/jwm/article/view/47.

Rachmania, Dewi. 2017. "Pengaruh Corporate Governance, Corporate Social Responsibility Dan Komisaris Independen Terhadap Nilai Perusahaan Pada Industri Tekstil dan Garmen Periode 2011-2013." COMPETITIVE: Jurnal Akuntansi Dan Keuangan 1 (1): 38-62. http://dx.doi.org/10.31000/competitive.v1i1.107.

Sanjaya, Surya, and Muhammad Fajri Rizky. 2018. "Analisis Profitabilitas Dalam Menilai Kinerja Keuangan Pada PT. Taspen (Persero) Medan.” Kitabah: Jurnal Akuntansi Dan Keuangan Syariah 2 (2): 277-293. http://jurnal.uinsu.ac.id/index.php/JAKS/article/view/4152.

Setiawan, Yudha Dwi Adi, and Astri Fitria. 2015. "Pengaruh Good Corporate Governance Terhadap Kinerja Perusahaan Pada Perusahaan Manufaktur Di BEI." Jurnal Ilmu dan Riset Akuntansi (JIRA) 4 (3): 1-21. http://jurnalmahasiswa.stiesia.ac.id/index.php/jira/article/view/3401. 
Setyarini, Maisiska, Andi Manggala Putra, and Ranti Nugraheni. 2021. "Perubahan Ukuran Komite Audit Dan Dewan Direksi Terhadap Kinerja Keuangan Pada Perusahaan Sektor Keuangan." Jurnal Akuntansi Aktual 8 (1): 65-76. http://dx.doi.org/10.17977/um004v8i12021p065.

Sobel, Michael E. 1982. "Asymptotic Confidence Intervals for Indirect Effects in Structural Equation Models." Sociological Methodology 13: 290-312. https://doi.org/10.2307/270723.

Spence, Michael. 1973. "Job Market Signaling.". Quarterly Journal of Economics 87 (3): 355-374. https://doi.org/10.1016/B978-0-12-214850-7.50025-5.

Suciwati, Desak Putu, Desak Putu Arie Pradnyan, and Cening Ardina. 2017. "Pengaruh Corporate Social Responsibility Terhadap Kinerja Keuangan (Pada Perusahaan Sektor Pertambangan di BEI Tahun 2010-2013)." Jurnal Bisnis dan Kewirausahaan 12 (2): http://ojs.pnb.ac.id/index.php/JBK/article/view/39.

Sudibya, Diva Cicilya Nunki Arun, and M. I. Mitha Dwi Restuti. 2014. "Pengaruh Modal Intelektual Terhadap Nilai Perusahaan Dengan Kinerja Keuangan Sebagai Variabel Intervening." BENEFIT: Jurnal Manajemen dan Bisnis 18

14-29. https://journals.ums.ac.id/index.php/benefit/article/view/1390.

Suffah, Roviqotus, and Akhmad Riduwan. 2016. "Pengaruh Profitabilitas, Leverage, Ukuran Perusahaan Dan Kebijakan Dividen Pada Nilai Perusahaan." Jurnal Ilmu dan Riset Akuntansi (JIRA) 5 (2): 1-17. http://jurnalmahasiswa.stiesia.ac.id/index.php/jira/article/view/274.

Sukirni, Dwi. 2012. "Kepemilikan Manajerial, Kepemilikan Institusional, Kebijakan Deviden dan Kebijakan Hutang Analisis Terhadap Nilai Perusahaan." Accounting Analysis Journal 1 (2): 1-12. https://journal.unnes.ac.id/sju/index.php/aaj/article/view/703.

Sukmono, Sigit, and Winwin Yadiati. 2016. "Effect of Board of Commissioner and Audit Committee on The Firm Value With Mediating Effect Financial Reporting Quality." Research Journal of Finance and Accounting 7 (2): 131-148. https://iiste.org/Journals/index.php/RJFA/article/view/28539.

Surya, Indra, and Ivan Yustiavandana. 2006. Penerapan Good Corporate Governance: Mengesampingkan Hak-Hak Istimewa Demi Kelangsungan Usaha. Skripsi Universitas Sintuwu Maroso.

Susanti, R., and Titik Mildawati. 2014. "Pengaruh Kepemilikan Manajemen, Kepemilikan Institusional dan Corporate Social Responsibility Terhadap Nilai Perusahaan." Jurnal Ilmu dan Riset Akuntansi 3 (1): 1-18.

Susanto, Cinditya Marina, and Lilis Ardini. 2016. "Pengaruh Good Corporate Governance, Corporate Social Responsibility, Dan Profitabilitas Terhadap Nilai Perusahaan." Jurnal Ilmu dan Riset Akuntansi (JIRA) 5 (7): 1-17. http://jurnalmahasiswa.stiesia.ac.id/index.php/jira/article/view/1846.

Sutedi, Adrian. 2012. Good Corporate Governance. Jakarta: Paragonatama Jaya. Tjahjono, Achmad, and Siti Chaeriyah. 2017. "Pengaruh Good Corporate Governance Terhadap Nilai Perusahaan Dengan Variabel Intervening Profitabilitas." Kajian Bisnis Sekolah Tinggi Ilmu Ekonomi Widya Wiwaha 25 (1): 13-39. http://jurnal.stieww.ac.id/index.php/jkb/article/view/141.

Wardani, Dewi Kusuma, and Sri Hermuningsih. 2011. "Pengaruh Struktur Kepemilikan Terhadap Nilai Perusahaan Dengan Kinerja Keuangan Dan 
Kebijakan Hutang Sebagai Variabel Intervening." Jurnal Siasat Bisnis 15 (1): 27-36. https://journal.uii.ac.id/index.php/JSB/article/view/3190.

Wardhani, Rulyanti Susi. 2013. "Pengaruh CSR Disclosure Terhadap Nilai Perusahaan Dengan Kinerja Keuangan Sebagai Variabel Intervening (Studi Kasus Perusahaan Manufaktur Yang Terdaftar Di BEI)." Jurnal Ekonomi Akuntansi Dan Manajemen 12 (1): 54-86. http://jurnal.unej.ac.id/index.php/JEAM/article/view/1184.

Widyasari, Nita Ayu, Suhadak Suhadak, and Achmad Husaini. 2015. "Pengaruh Good Corporate Governance (GCG) dan Pengungkapan Corporate Social Responsibility (CSR) Terhadap Nilai Perusahaan (Studi Pada Perusahaan Manufaktur Yang Terdaftar Di BEI Periode 2011-2013)." Jurnal Administrasi $\quad$ Bisnis $\quad 26 \quad$ (1): http://administrasibisnis.studentjournal.ub.ac.id/index.php/jab/article/view/ 1021. 